\title{
Monosomy 9q22.3
}

INSERM

\section{Source}

INSERM. (1999). Orphanet: an online rare disease and orphan drug data base.

Monosomy 9q22.3. ORPHA:77301

Interstitial 9q22.3 microdeletion is associated with a phenotype including macrocephaly, overg rowth and trigonocephaly. Psychomotor delay, hyperactivity and distinctive facial features were also observed. It has been described in two unrelated children. 